\title{
Towards gene therapy against HIV-1: new therapeutic target in gag RNA accessible to ribozymes and RNA interference molecules
}

\author{
${\text { A Gatignol }{ }^{1 *}, \text { RJ Scarborough }{ }^{1}, \text { MV Lévesque }}^{2}$, E Boudrias-Dalle ${ }^{1}$, IC Chute ${ }^{3}$, SM Daniels ${ }^{1}$, RJ Ouellette ${ }^{3}$, J-P Perreault ${ }^{2}$ \\ From International Symposium HIV and Emerging Infectious Diseases 2014 \\ Marseille, France. 21-23 May 2013
}

\begin{abstract}
Aim
Antisense molecules targeting HIV-1 RNA have the potential to be used as part of combination gene or drug therapy to treat HIV-1 infection to reach a functional or complete cure. Only a small number of extremely active molecules currently exist and a treatment option has not yet been identified in clinical trials. We have previously developed new hepatitis delta virus (HDV)-derived ribozymes (Rzs) called "switch on-off adaptor" (SOFA) to target HIV-1 RNA [1]. Our aim is to develop highly active RNA-based molecules with complementary mechanisms, which are able to reach a large number of HIV-1 variants.
\end{abstract}

\section{Methods}

We screened HIV-1 RNA to identify conserved target sites for new HDV-Rzs [2]. We designed new SOFA-HDV-Rzs against the Gag RNA and developed a rapid test to evaluate the inhibition of HIV-1 production. We designed small interfering (si) RNAs targeting the same region and tested their activity on HIV-1 replication.

\section{Results}

We identified 13 conserved regions in the gag RNA and constructed the corresponding Rzs. We transfected HEK293T cells with these Rzs and HIV-1 molecular clones. We identified one $\mathrm{Rz}$ that was particularly efficacious. We then constructed siRNAs and short hairpin (sh) RNAs targeting the same sequence. The shRNA was very active against HIV-1 clades B, C and A/G. Neither the Rz, nor the shRNA disturbs the cellular transcriptome, suggesting no toxicity. In lymphocytic cell lines, both the $\mathrm{Rz}$ and the shRNA inhibit long-term HIV-1 replication [2].

\footnotetext{
'Lady Davis Institute for Medical Research, McGill University, Montreal, Canada

Full list of author information is available at the end of the article
}

\section{Conclusions}

We identified new SOFA-HDV-Rz, siRNA and shRNA targeting HIV-1 Gag RNA. The shRNA is as active as the only shRNA that has advanced to clinical trials and targets more strains. Long-term inhibitory activity of these molecules shows that this site is particularly accessible to other antisense molecules. These molecules have a high potential to be used in combination gene therapy or as drugs with appropriate delivery methods.

\section{Authors' details}

'Lady Davis Institute for Medical Research, McGill University, Montreal,

Canada. ${ }^{2}$ Department of Biochemistry, University of Sherbrooke, Sherbrooke, Canada. ${ }^{3}$ Atlantic Institute for research on cancer, Moncton, Canada.

\section{Published: 23 May 2014}

\section{References}

1. Lainé S, et al: RNA Biol. 2011, 8:343.

2. Scarborough RJ, et al: Methods Mol Biol. 2014, 1103:31.

doi:10.1186/1471-2334-14-S2-O19

Cite this article as: Gatignol et al:: Towards gene therapy against HIV-1: new therapeutic target in gag RNA accessible to ribozymes and RNA interference molecules. BMC Infectious Diseases 2014 14(Suppl 2):O19.

Submit your next manuscript to BioMed Central and take full advantage of:

- Convenient online submission

- Thorough peer review

- No space constraints or color figure charges

- Immediate publication on acceptance

- Inclusion in PubMed, CAS, Scopus and Google Scholar

- Research which is freely available for redistribution 